\title{
RECOVERY ENZIM KATEPSIN DARI LIMBAH CAIR SURIMI
}

\author{
Tati Nurhayati, Hani Novanti, dan Agoes M Jacoeb \\ Departemen Teknologi Hasil Perairan Fakultas Perikanan dan IImu Kelautan IPB \\ Jl. Agatis Kampus IPB Dramaga, Bogor 16680 \\ Email: nurhayati7870@yahoo.com
}

\begin{abstract}
Surimi processing waste liquid that still contains high sarcoplasmic proteins that can still be used, one of which is an cathepsin enzyme. The purpose of the study was to determine the parameters of $\mathrm{pH}$ and temperature in recovery of enzyme cathepsin from surimi wastewater. The results showed that the best recovery of cathepsin enzyme is obtained at pre-treated $\mathrm{pH} 5$ and heating at a temperature of $60{ }^{\circ} \mathrm{C}$. In these conditions, cathepsin enzyme has a specific activity $17.90 \mathrm{U} / \mathrm{mg}$ and a multiple of 117 times the purity of surimi wash water.
\end{abstract}

Keywords: cathepsin, enzyme recovery, $\mathrm{pH}$, surimi wastewater, temperature

\section{PENDAHULUAN}

Surimi adalah protein miofibril dari daging ikan yang terstabilisasi dengan cara membuang tulang dan kulit dari daging ikan secara mekanis yang dicuci dengan air dan dicampur dengan krioprotektan. Surimi merupakan produk intermediet dari ikan yang digunakan untuk berbagai macam produk pangan diantaranya kamaboko (Lin et al. 1995).

Limbah dari hasil pembuatan surimi yang berupa padatan biasanya dikonversi menjadi pakan ternak atau ikan, namun limbah yang berupa cairan hanya dibuang begitu saja. Hal tersebut dapat menimbulkan pencemaran lingkungan karena kandungan organik yang sangat tinggi. Lin et al. (1995) melaporkan bahwa kadar Biological Oxygen Demand (BOD) dari proses pencucian surimi sebesar 6000-27000 mg/l.

Limbah air cucian surimi tersebut masih dapat dimanfaatkan karena banyak mengandung bahan organik. Menurut DeWitt dan Morrisey (2001), air cucian surimi tidak hanya mengandung protein sarkoplasma, namun juga protein miofibril, protease, hemepigment, dan komponen bioaktif potensial lainnya. Recovery komponen bioaktif dari air cucian surimi, misal protease, dapat meningkatkan nilai tambah dari limbah industri surimi.

Aplikasi dari protease dapat ditemukan dalam berbagai macam produk dalam industri makanan. Beberapa contoh dari aplikasinya adalah pemisahan protein dari tulang, produksi hidrolisat, pengempukkan daging, penjernihan, dan fermentasi (Haard 1992). An et al. (1994) juga telah mengidentifikasi katepsin $\mathrm{L}$ sebagai protease utama yang bertanggung jawab terhadap degradasi miosin dalam pembuatan surimi.

Metode yang dilakukan dalam recovery enzim katepsin adalah filtrasi menggunakan membran. Masalah yang ditimbulkan dalam proses filtrasi adalah terjadinya fouling pada membran. Masalah tersebut dapat diatasi dengan menggunakan proses pretreatment menggunakan asam dan pengaturan suhu. 
Tujuan dari penelitian ini adalah menentukan $\mathrm{pH}$ dan suhu terbaik dalam pra-perlakuan recovery enzim katepsin dari air cucian surimi.

\section{METODE}

\section{Bahan dan Alat}

Bahan utama yang digunakan penelitian ini adalah ikan lele (Clarias gariepinus) ukuran 10/kg dan asam klorida ( $\mathrm{HCl})$. Bahan-bahan yang digunakan untuk pengujian adalah hemoglobin $2 \%$, buffer Tris- $\mathrm{Cl}(\mathrm{pH} \mathrm{7,4,0,1}$ $\mathrm{mL})$, TCA $5 \%(\mathrm{w} / \mathrm{v})$, pereaksi folin, tirosin, bovine serum albumin (BSA), coomasive brilliant blue G-250, etanol $95 \%(\mathrm{v} / \mathrm{v})$, dan asam fosfat $85 \%(\mathrm{v} / \mathrm{v})$.

Alat-alat yang digunakan untuk penelitian meliputi, waterbath, sentrifuge, freezer, timbangan digital, $\mathrm{pH}$ meter, labu erlenmeyer $50 \mathrm{~mL}$, dan peralatan gelas lainnya. Peralatan untuk pengujian meliputi kertas saring, inkubator, spektrofotometer, timbangan digital, dan peralatan gelas lainnya.

\section{Lingkup Penelitian}

Penelitian ini dilakukan dalam empat tahap. Tahap pertama adalah pembuatan air cucian surimi dari ikan lele (Clarias gariephinus). Tahap kedua adalah perlakuan air cucian surimi menggunakan suhu yang berbedabeda diikuti dengan pengujian kadar protein dan aktivitas enzim katepsin. Tahap ketiga adalah perlakuan air cucian surimi menggunakan asam dengan $\mathrm{pH}$ berbeda yang diikuti dengan pengujian kadar protein dan aktivitas enzim katepsin. Tahap keempat adalah memanaskan sampel dari perlakuan asam menggunakan suhu terbaik dari tahap sebelumnya dan diikuti dengan analisis kadar protein serta aktivitas enzim katepsin. Setiap perlakuan dan proses analisis menggunakan tiga kali ulangan.

\section{Preparasi air cucian surimi dari ikan lele (Clarias gariephinus)}

Ikan lele yang dipakai dibeli dalam keadaan hidup. Ikan tersebut kemudian dipreparasi dan difillet. Ikan dicacah menggunakan pisau dan digiling menjadi mince menggunakan meat grinder. Daging tersebut kemudian dicuci menggunakan air dingin dengan perbandingan air dan daging sebesar 3:1. Daging yang sudah dicuci diperas airnya menggunakan kain belacu. Air perasan atau air cucian tersebut kemudian dipakai sebagai bahan penelitian.

\section{Analisis proksimat air cucian surimi}

Air cucian surimi yang telah diambil dianalsis untuk mengetahui kandungan di dalamnya. Analisis yang dilakukan adalah uji kadar air, abu, dan protein.

1) Kadar air (AOAC 2005)

Proses analisis diawali dengan mengeringkan cawan porselen kosong dalam oven selama 15 menit. Cawan tersebut kemudian didinginkan dalam deksikator selama 20 menit, selanjutnya ditimbang. Sampel air cucian surimi sebanyak 5 gram dimasukkan ke dalam cawan kemudian dikeringkan dalam oven suhu $100^{\circ} \mathrm{C}$. Tekanan yang digunakan tidak lebih dari $100 \mathrm{mmHg}$. Proses pengovenan dilakukan selama lima jam atau sampai beratnya konstan. Cawan berisi sampel yang telah dioven didinginkan dalam desikator, selanjutnya ditimbang. Perhitungan kadar air menggunakan rumus berikut.

Keterangan :

$$
\text { Kadar air }(\%)=\frac{B-C}{B-A} \times 100 \%
$$

$\mathrm{A}=$ berat cawan kosong (gram)

$\mathrm{B}=$ berat cawan + sampel awal (gram)

$\mathrm{C}=$ berat cawan + sampel kering (gram)

\section{2) Kadar abu (AOAC 2005)}

Cawan pengabuan dikeringkan dalam oven selama satu jam pada suhu $105^{\circ} \mathrm{C}$. Cawan tersebut kemudian didinginkan selama 15 menit dalam desikator, selanjutnya ditimbang. Sampel sebanyak lima gram dimasukkan ke dalam cawan pengabuan dan dipijarkan di atas kompor listrik hingga proses tersebut tidak menghasilkan asap. Cawan tersebut kemudian dimasukkan ke dalam tanur pengabuan selama enam jam pada suhu $400^{\circ} \mathrm{C}$. Cawan tersebut selanjutnya didinginkan dalam desikator, kemudian 
ditimbang. Penentuan kadar abu dihitung dengan menggunakan rumus berikut.

$$
\text { Kadar abu(\%) }=\frac{\text { Berat abu }(\mathrm{g})}{\text { Berat sampel }(\mathrm{g})} \times 100 \%
$$

Berat abu $(\mathrm{g})=$ berat sampel dan cawan akhir (g) - berat cawan kosong (g)

3) Kadar protein (AOAC 2005)

Analisis kadar protein terdiri dari tiga tahap, yaitu destruksi, destilasi, dan titrasi. Pengukuran kadar protein dilakukan dengan metode mikro Kjeldahl. Sampel ditimbang sebanyak 5 gram dimasukkan ke dalam labu Kjeldahl $100 \mathrm{~mL}$. Sebanyak 1 tablet katalis dan $3 \mathrm{~mL} \mathrm{H} 2 \mathrm{SO} 4$ pekat serta sampel didekstruksi (pemanasan dalam keadaan mendidih) pada suhu $410^{\circ} \mathrm{C}$ selama 2 jam atau sampai hijau bening. Setelah dingin diencerkan hingga $100 \mathrm{~mL}$ dan diambil $10 \mathrm{~mL}$ untuk destilasi. Larutan tersebut setelah dingin ditambah dengan $50 \mathrm{~mL}$ akuades dan

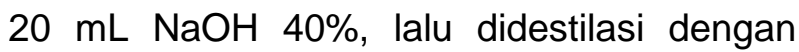
suhu destilator $100^{\circ} \mathrm{C}$. Hasil destilasi ditampung dalam labu erlenmeyer yang berisi campuran $10 \mathrm{~mL} \mathrm{H} 3 \mathrm{BO} 32 \%$ dan 2 tetes indikator bromchrerol green-methyl red bewarna merah muda (1:2). Setelah volume hasil tampungan (destilat) menjadi $40 \mathrm{~mL}$ dan berwarna hijau kebiruan, destilasi dihentikan dan destilat dititrasi dengan $\mathrm{HCl} 0,10 \mathrm{~N}$ sampai berwarna merah muda. Perlakuan yang sama dilakukan juga terhadap blanko. Kadar protein dihitung dengan rumus sebagai berikut:

$$
\begin{gathered}
\mathrm{N}(\%)=\frac{(\mathrm{mL} \mathrm{HCl}-\mathrm{mL} \text { blanko }) \times \mathrm{NHCl} \times \text { faktor pengenceran } \times 14,007}{\mathrm{mg} \text { contoh } \times \text { faktor koreksi alat }} \times 100 \% \\
\text { Protein }(\%)=\mathrm{N}(\%) \times 6,25
\end{gathered}
$$

\section{Perlakuan air cucian surimi dengan suhu (DeWitt dan Morrissey 2001)}

Air cucian surimi diberi perlakuan panas. Pemanasan dilakukan dengan cara menempatkan $10 \mathrm{~mL}$ air cucian dalam $50 \mathrm{~mL}$ erlenmeyer yang ditutup alumunium foil dan diletakkan dalam waterbath dengan suhu $30^{\circ} \mathrm{C}, 40^{\circ} \mathrm{C}, 50^{\circ} \mathrm{C}, 60^{\circ} \mathrm{C}$, dan $70^{\circ} \mathrm{C}$ selama 10 menit. Setelah dipanaskan, sampel didinginkan secara singkat dalam bak berisi es dan disentrifugasi pada $3.000 \mathrm{~g}$ selama 6 menit, suhu $4^{\circ} \mathrm{C}$. Supernatan yang dihasilkan diambil dan dismpan dalam freezer. Kemudian supernatan tersebut dianalisis aktivitas enzim katepsin (Dinu et al. 2002) dan kadar proteinnya (Bradford 1976). Suhu dengan aktivitas enzim katepsin tertinggi yang diperoleh dijadikan sebagai acuan untuk pemanasan yang dilakukan setelah perlakuan dengan asam.

\section{Perlakuan air cucian surimi dengan asam (DeWitt dan Morrissey 2001)}

Air cucian surimi diberi perlakuan dengan asam, yaitu asam klorida $(\mathrm{HCl})$. Air cucian
$(20,0 \mathrm{~g})$ diberi perlakuan dengan $\mathrm{HCl}$ dengan pengaturan $\mathrm{pH} 1$ dan $0,1 \mathrm{~N}$. Volume akhir adalah $25,0 \mathrm{~mL}$ dengan akuades. Target $\mathrm{pH}$ yang akan dipakai adalah $7 ; 6,0 ; 5,0 ; 4,0$; dan 3,0 . Semua preparasi dilakukan secara duplo. Sampel yang telah diberi asam langsung disentrufugasi pada $3.000 \mathrm{~g}$ selama 6 menit dan suhu $4{ }^{\circ} \mathrm{C}$. Supernatan yang dihasilkan diambil dan diuji aktivitas enzimnya (Dinu et al. 2002) katepsin dan kadar proteinnya (Bradford 1976) serta pH akhir dihitung. Setelah itu disimpan pada suhu rendah di dalam freezer sampai dilakukan analisis lebih lanjut. Supernatan yang tersisa diberi perlakuan dengan panas.

\section{Perlakuan air cucian surimi dengan kombinasi asam dan pemanasan (DeWitt dan Morrissey 2001)}

Air cucian surimi yang telah diberi perlakuan dengan asam diambil sebanyak 10 $\mathrm{mL}$ untuk dipanaskan dengan suhu terbaik yang diperoleh dari perlakuan sebelumnnya. Air cucian surimi tersebut dipanaskan menggunakan waterbath dalam tabung 
erlenmeyer $50 \mathrm{~mL}$ dan dibungkus dalam aluminum foil selama 10 menit. Sampel yang telah dipanaskan kemudian disentrifugasi kembali pada $3000 \mathrm{~g}$ selama 6 menit, suhu $4^{\circ} \mathrm{C}$. Kemudian supernatan tersebut dianalisis aktivitas enzim katepsin (Dinu et al. 2002) dan kadar proteinnya (Bradford 1976).

\section{Analisis}

1) Aktivitas katepsin (Dinu et al. 2002)

Aktivitas proteolitik katepsin diuji menggunakan hemoglobin sebagai substratnya dengan konsentrasi $2 \% \mathrm{pH} 2$. Sebanyak 0,5 mL larutan substrat, $\quad 01 \mathrm{~mL}$ buffer Tris-Cl pH 7,4 diinkubasi dengan 0,1 $\mathrm{mL}$ larutan enzim pada $37^{\circ} \mathrm{C}$ selama 10 menit. Reaksi dihentikan dengan penambahan $2 \mathrm{~mL}$ TCA 5\% (w/v). Campuran disaring dan $1 \mathrm{~mL}$ filtrat hasil penyaringan ditambah dengan $1 \mathrm{~mL}$ pereaksi folin. Campuran kemudian diukur dengan spektrofotometer pada panjang gelombang $750 \mathrm{~nm}$. Selain itu, dilakukan pula pengukuran untuk larutan blanko dan larutan standar enzimnya digantikan dengan akuades dan tirosin. Unit didefinisikan sebagai banyaknya enzim yang dapat mengubah substrat menjadi $1 \mu \mathrm{mol}$ tirosin dalam 1 menit.

Aktivitas enzim katepsin dapat dihitung dengan rumus berikut:

$U A=\frac{\text { (Absorbansi sampel-absorbansi blanko) }}{\text { (Absorbansi standar-absorbansi blanko) }} \times \mathrm{P} \times \frac{1}{\mathrm{~T}}$

Keterangan: UA = jumlah tirosin yang dihasilkan per ml enzim per menit

$$
\begin{aligned}
& \mathrm{P}=\text { faktor pengenceran } \\
& \mathrm{T} \text { = waktu inkubasi }
\end{aligned}
$$

\section{2) Pengukuran konsentrasi protein (Bradford 1976)}

Konsentrasi protein ditentukan menggunakan metode Bradford dengan bovine serum albumin sebagai standar. Persiapan peraksi Bradford dilakukan dengan cara melarutkan $5 \mathrm{mg}$ coomasive briliant blue G-250 dalam 2,5 mL etanol 95\% (v/v). Jika telah larut dengan sempurna lalu ditambah 5
$\mathrm{mL}$ asam fosfat $85 \%(\mathrm{v} / \mathrm{v})$. Jika telah larut dengan sempurna ditambah akuades hingga $250 \mathrm{~mL}$ dan disaring dengan kertas saring Whatman no. 1 serta diencerkan 5 kali sesaat sebelum digunakan.

Konsentrasi protein ditentukan menggunakan metode Bradford dengan cara $0,1 \mathrm{~mL}$ enzim dimasukkan ke dalam tabung reaksi, kemudian ditambah $5 \mathrm{~mL}$ peraksi Bradford, dan diinkubasi selama 5 menit serta diukur dengan spektrofotometer pada panjang gelombang $595 \mathrm{~nm}$. Demikian pula untuk larutan standar dilakukan sama seperti larutan sampel dengan konsentrasi antara 0-3,2 $\mathrm{mg} / \mathrm{mL}$. Tahap berikutnya adalah membuat kurva standar dengan absorbansi sebagai ordinat (sumbu y) dan konsentrasi protein sebagai absis (sumbu $\mathrm{x}$ ). Bedasarkan kurva tersebut dapat ditentukan konsentrasi protein dalam sampel. Komposisi volume larutan dengan pembuatan larutan standar dengan konsentrasi $0,04-3,2 \mathrm{mg} / \mathrm{mL}$ larutan BSA dapat dilihat pada Tabel 1.

\section{HASIL DAN PEMBAHASAN \\ Analisis Kimia Air Cucian Surimi}

Air cucian surimi diambil pada proses pencucian mince ikan lele. Air cucian yang telah diambil dianalsis kandungan air, abu, dan protein sebelum diberi perlakuan. Air cucian surimi tersebut juga dianalisis aktivitas enzim katepsin dan aktivitas spesifik enzim katepsinnya. Hasil analisis kimia air cucian surimi dapat dilihat pada Tabel 2.

Hasil analisis kimia air cucian surimi menunjukkan adanya protein pada air cucian surimi, yaitu sebesar $0,88 \%$. Kadar protein tersebut cenderung lebih rendah dibandingkan dengan penelitian Lin et al. (1995) yang sebesar 2,34\%. Perbedaan kadar protein tersebut disebabkan oleh perbedaan proses produksi surimi yang dilakukan. Air cucian surimi yang diperoleh untuk proses penelitian diperoleh dengan cara memeras daging cincang ikan lele menggunakan kain belacu. Hal ini menyebabkan kurang maksimalnya pencucian daging ikan dibandingkan menggunakan mesin yang berada di pabrik pembuatan surimi. 


\section{Pengaruh Suhu, pH, dan Kombinasi Keduanya terhadap Aktivitas Enzim Katepsin}

Enzim sangat sensitif terhadap perubahan suhu. Reaksi enzim yang dikatalisasi mengikuti aturan yang sama dengan reaksi kimia biasa yang terjadi peningkatan aktivitas 2-3 faktor setiap $10^{\circ} \mathrm{C}$ bedasarkan aturan van t'Hoff. Tidak ada batas ketinggian suhu secara teoritis, namun setelah tercapai temperatur maksimal reaksi katalis enzim akan menurun sampai titik nol. Penurunan ini terjadi akibat denaturasi protein seiring meningkatnya suhu (Bisswanger 2008). Pengaruh suhu terhadap aktivitas enzim katepsin pada air cucian surimi dapat dilihat pada Gambar 1.

Gambar 1 menunjukkan aktivitas enzim katepsin meningkat seiring dengan peningkatan suhu sampai dengan suhu optimum yaitu $60^{\circ} \mathrm{C}$ namun mengalami penurunan pada suhu $70^{\circ} \mathrm{C}$. Aktivitas enzim katepsin air cucian surimi paling tinggi terdapat pada suhu $60^{\circ} \mathrm{C}$ yaitu sebesar 0,475 $\mathrm{U} / \mathrm{mL}$. Hasil aktivitas tersebut berbeda nyata $(p<0,1)$ pada masing-masing perlakuan. Hasil tersebut sesuai dengan penelitian DeWitt dan Morrissey (2001) terhadap aktivitas enzim katepsin $L$ pada air cucian surimi yaitu enzim katepsin memiliki aktivitas paling tinggi pada suhu $60^{\circ} \mathrm{C}$. Suhu pemanasan tersebut dijadikan acuan untuk pemanasan air cucian surimi pada perlakuan kombinasi penambahan asam dan pemanasan.

Penelitian lain yang dilakukan oleh Krause et al. (2010) terhadap enzim katepsin D yang berasal dari daging ikan ostrich menyebutkan bahwa katepsin $\mathrm{D}$ memiliki aktivitas optimal pada suhu $45^{\circ} \mathrm{C}$. Penelitian lain yang dilakukan oleh Jiang et al. (2002) terhadap katesin $\mathrm{D}$ ikan tongkol dan ikan bandeng, menyatakan enzim katepsin pada ikan tongkol akan memiliki aktivitas tertinggi pada suhu $45^{\circ} \mathrm{C}$ dan pada ikan bandeng pada suhu $50^{\circ} \mathrm{C}$.

Proses pengikatan antara enzim dengan substrat dan reaksi katalisisnya tergantung pada interaksi antara substrat dengan rantai samping asam amino yang menyusun sisi aktif enzim (Bender 2002). Peristiwa ini harus berada pada keadaan ionisasi yang tepat untuk mengikat. Pengikatan tersebut tergantung pada $\mathrm{pH}$ medium.

Reaksi enzim dipengaruhi oleh $\mathrm{pH}$ medium tempat reaksi terjadi. Setiap enzim memiliki $\mathrm{pH}$ optimum yang khas. Profil aktivitas $\mathrm{pH}$ enzim menggambarkan $\mathrm{pH}$ pada saat pemberi dan penerima proton yang penting pada sisi katalitik enzim berada pada tingkat ionisasi yang diinginkan. Perubahan $\mathrm{pH}$ yang ekstrim dapat menyebabkan enzim terdenaturasi sehingga enzim kehilangan aktivitas biologisnya (Lehninger 1993). Pengaruh tingkat keasaman terhadap aktivitas enzim katepsin disajikan pada Gambar 2.

Hasil perlakuan sampel pada $\mathrm{pH} 6$ dan 7 tidak berbeda nyata $(p>0,1)$ namun mengalami kenaikan yang signifikan $(p<0,1)$ seiring dengan penurunan $\mathrm{pH}$. Aktivitas yang paling tinggi terdapat pada $\mathrm{pH} 3$ yaitu sebesar $0,59 \mathrm{U} / \mathrm{mL}$. Hal ini sesuai dengan pendapat dari Choi et al. (2005) bahwa enzim katepsin aktif pada $\mathrm{pH}$ asam. Sementara penelitian yang dilakukan Toyohara et al. (1981) pada carp muscle, bahwa katepsin $\mathrm{A}$ memiliki $\mathrm{pH}$ optimum 5. Penelitian yang dilakukan oleh Krause et al. (2010) terhadap enzim katepsin D yang berasal dari daging ikan ostrich menyebutkan bahwa katepsin D memiliki aktivitas optimal pada $\mathrm{pH}$ 4. Penelitian lain yang dilakukan oleh Jiang et al. (2002) terhadap katesin $\mathrm{D}$ ikan tongkol dan ikan bandeng, menyatakan bahwa katepsin $\mathrm{D}$ memiliki aktivitas tertinggi pada $\mathrm{pH}$ 5,04 (ikan tongkol) dan $\mathrm{pH} 4,91$ (ikan bandeng).

Hasil aktivitas enzim katepsin pada yang diberi perlakuan asam dan suhu mengalami peningkatan yang signifikan $(p<0,1)$ seiring dengan peningkatan $\mathrm{pH}$ sampai pada $\mathrm{pH} 5$ $(0,64 \mathrm{U} / \mathrm{mL})$. Aktivitas enzim katepsin pada $\mathrm{pH}$ 5 dan 6 tidak berbeda nyata $(p>0,1)$ namun mengalami penurunan yang signifikan pada pH $7 \quad(p<0,1)$. Grafik pengaruh perlakuan asam dan pemanasan pada suhu $60^{\circ} \mathrm{C}$ terhadap aktivitas enzim katepsin dapat dilihat pada Gambar 3. Aktivitas enzim katepsin yang diberi perlakuan $\mathrm{pH}$ mengalami peningkatan saat dipanaskan pada suhu $60^{\circ} \mathrm{C}$ 
dari kisaran $0,3500 \mathrm{U} / \mathrm{mL}$ sampai 0,5917 $\mathrm{U} / \mathrm{mL}$ menjadi $0,3917 \mathrm{U} / \mathrm{mL}$ sampai 0,6417 $\mathrm{U} / \mathrm{mL}$. Aktivitas enzim menjadi optimum pada $\mathrm{pH} 5(0,64 \mathrm{U} / \mathrm{mL})$.

Perubahan ini sangat mungkin terjadi karena kombinasi efek dari penambahan asam dan pemanasan saat terjadinya denaturasi protein. Proses pengasaman sendiri mengakibatkan denaturasi protein sebagai hasil dari penolakan elektrostatik. Proses denaturasi berlanjut akibat pemanasan yang melemahkan ikatan ionik (Damodaran 1996 diacu dalam Mireles DeWitt 2001).

Beberapa penelitian (Seymour et al. 1994; An et al. 1995; Benjakul et al. 1996) menyatakan bahwa aktivitas enzim katepsin pada air cucian surimi dari ikan Pasific whiting meningkat akibat perlakuan suhu atau asam. Peningkatan tersebut diakibatkan oleh denaturasi inhibitor indogenous yang tidak stabil. Kombinasi efek pengasaman dan pemanasan pada suhu $60^{\circ} \mathrm{C}$ menyebabkan inhibitor indogenous terdenaturasi pada $\mathrm{pH}$ yang lebih tinggi.

\section{Pengaruh Suhu, pH, dan Kombinasi Keduanya terhadap Kadar Protein}

Sampel dari masing-masing perlakuan diukur kadar proteinnya. Kadar protein pada suhu $30^{\circ} \mathrm{C}, 40^{\circ} \mathrm{C}, 50^{\circ} \mathrm{C}$, dan $60^{\circ} \mathrm{C}$ tidak berbeda nyata $(p>0,1)$ dan mengalami penurunan yang signifikan $(p<0,1)$ pada suhu $70^{\circ} \mathrm{C}$. Gambar 4 menunjukkan bahwa kadar protein semakin menurun seiring dengan kenaikan suhu. Hal ini sesuai dengan penelitian Bourtoom et al. (2009) yang menyatakan kenaikan suhu berpengaruh terhadap pengendapan protein dalam air cucian surimi. Pengendapan tersebut terjadi karena adanya denaturasi protein. Campbell dan Farrel (2006) menyatakan bahwa denaturasi protein tersebut terjadi karena kenaikan suhu yang menyebabkan terjadinya getaran antar molekul. Getaran tersebut cukup tinggi sehingga dapat menyebabkan kerusakan struktur tertier protein.

Kadar protein air cucian surimi pada $\mathrm{pH} 3$, 4,5 , dan 6 tidak berbeda nyata $(p>0,1)$ namun mengalami peningkatan yang signifikan $(\mathrm{p}<0,1)$ pada $\mathrm{pH} 7(32,433 \mu \mathrm{g} / \mathrm{mL})$. Grafik pengaruh $\mathrm{pH}$ terhadap kadar protein dapat dilihat pada Gambar 5. Kadar protein yang paling rendah terdapat pada $\mathrm{pH} 4$ $(32,304 \mu \mathrm{g} / \mathrm{mL})$. Hal ini mungkin terjadi karena titik isoelektrik $(\mathrm{pl})$ dari protein yang terdapat dalam air cucian surimi tercapai pada $\mathrm{pH} 4$. Denaturasi terjadi pada pl karena hilangnya gaya tolak-menolak elektrotasis pada molekul. Penurunan kadar protein juga mengalami penunurunan pada $\mathrm{pH}$ yang rendah karena melemahnya ikatan ionik antar molekul protein yang menyebabkan terjadinya denaturasi protein (Campbell dan Farrel 2006).

Pengaruh $\mathrm{pH}$ dan pemanasan pada suhu $60^{\circ} \mathrm{C}$ terhadap kadar protein dapat dilihat pada Gambar 6. Kadar protein pada pH 3, 4, dan 5 tidak berbeda nyata $(p>0,01)$ namun namun mengalami peningkatan yang signifikan $(\mathrm{p}<0,1)$ pada $\mathrm{pH} 6$ dan menurun pada $\mathrm{pH}$ 7. Air cucian surimi yang diberi perlakuan asam dan dipanaskan pada suhu $60^{\circ} \mathrm{C}$ mengalami penurunan kadar protein dibandingkan yang hanya diberi perlakuan asam. Kadar protein menurun dari kisaran $32,304 \mu \mathrm{g} / \mathrm{mL}$ sampai $32,433 \mu \mathrm{g} / \mathrm{mL}$ menjadi $32,281 \mu \mathrm{g} / \mathrm{mL}$ sampai $32,307 \mu \mathrm{g} / \mathrm{mL}$. Penurunan kadar protein ini sesuai dengan hasil penelitian

Bourtoom et al. (2009) yang menyebutkan bahwa penurunan $\mathrm{pH}$ yang disertai kenaikan suhu dapat meningkatkan jumlah protein yang mengalami pengendapan akibat denaturasi.

\section{Pengaruh Suhu, pH, dan Kombinasi Keduanya terhadap Aktivitas Spesifik Enzim Katepsin}

Aktivitas spesifik enzim adalah pengukuran kemurnian larutan enzim. Aktivitas spesifik dihitung dengan cara membagi aktivitas enzim $(\mathrm{U} / \mathrm{mL})$ dengan kadar protein $(\mathrm{mg} / \mathrm{mL})$ sehingga diperoleh nilai aktivitas spesifik dengan satuan $\mathrm{U} / \mathrm{mg}$ (El-Yassin 2012). Nilai aktivitas spesifik enzim katepsin terhadap perubahan suhu dapat dilihat pada Gambar 8 .

Aktivitas spesifik enzim katepsin dengan perlakuan suhu berbeda nyata $(p<0,1)$ pada 
masing-masing perlakuan. Gambar 7 menunjukkan aktivitas spesifik enzim katepsin mengalami kenaikan seiring dengan kenaikan suhu dan mencapai puncaknya pada suhu $60^{\circ} \mathrm{C} \quad(14,70679 \mathrm{U} / \mathrm{mg})$ serta mengalami penurunan pada suhu $70^{\circ} \mathrm{C}$. Sementara penelitian yang dilakukan oleh Balti et al. (2010) terhadap katepsin D yang berasal dari hepatopankreas sotong menyatakan suhu tersebut memiliki aktivitas spesifik optimum pada $50^{\circ} \mathrm{C}$.

Hasil perlakuan sampel pada pH 6 dan 7 tidak berbeda nyata $(p>0,1)$ namun mengalami kenaikan yang signifikan $(p<0,1)$ seiring dengan penurunan $\mathrm{pH}$. Sampel yang diberi perlakuan dengan asam yang berbeda mengalami kenaikan seiring dengan penurunan $\mathrm{pH}$ (Gambar 8). Aktivitas spesifik mencapai puncaknya pada $\mathrm{pH} 3$, yaitu sebesar 18,3025 U/mg. Hal ini sesuai dengan penelitian yang dilakukan Balti et al. (2010) terhadap katepsin $\mathrm{D}$ yang berasal dari hepatopankreas sotong memiliki aktivitas spesifik optimum pada $\mathrm{pH} 3$.

Hasil aktivitas enzim katepsin pada yang diberi perlakuan asam dan pemanasan suhu $60^{\circ} \mathrm{C}$ mengalami peningkatan yang signifikan $(p<0,1)$ seiring dengan peningkatan $\mathrm{pH}$ sampai pada $\mathrm{pH} 5(17,89807 \mathrm{U} / \mathrm{mg})$. Aktivitas enzim katepsin pada pH 5 dan 6 tidak berbeda nyata $(p>0,1)$ namun mengalami penurunan yang signifikan pada $\mathrm{pH} 7(\mathrm{p}<0,1)$. Grafik pengaruh perlakuan asam dan pemanasan pada suhu $60^{\circ} \mathrm{C}$ terhadap aktivitas enzim katepsin dapat dilihat pada Gambar 9.

Aktivitas enzim katepsin yang diberi perlakuan $\mathrm{pH}$ mengalami peningkatan saat dipanaskan pada suhu $60^{\circ} \mathrm{C}$ dari kisaran $10,26191 \mathrm{U} / \mathrm{mg}$ sampai $16,64263 \mathrm{U} / \mathrm{mg}$ menjadi $14,71923 \mathrm{U} / \mathrm{mL}$ sampai 17,89807 $\mathrm{U} / \mathrm{mL}$. Gambar 10 menunjukkan aktivitas spesifik tertinggi pada pH $5(19,8708 \mathrm{U} / \mathrm{mg})$. Recovery enzim katepsin dari air cucian surimi bedasarkan aktivitas spesifik enzim katepsin tercapai pada $\mathrm{pH} 5$ dengan pemanasan pada suhu $60^{\circ} \mathrm{C}$.

\section{Pengaruh Suhu, pH, dan Kombina si Keduanya terhadap Tingkat Kemurnian Enzim Katepsin}

Tingkat kemurnian enzim katepsin dihitung dengan cara membagi aktivitas spesifik enzim katepsin setelah diberi perlakuan dengan aktivitas spesifik enzim katepsin sebelum diberi perlakuan. Tingkat kemurnian enzim diperlukan untuk mengetahui banyaknya enzim yang terdapat dalam sampel yang dipakai (Doonan dan Cutler 2004). Aktivitas spesifik dan tingkat kemurnian enzim katepsin dari masing-masing perlakuan dapat dilihat pada Tabel 3.

Tingkat kemurnian enzim katepsin meningkat seiring dengan peningkatan suhu sampai dengan suhu $60^{\circ} \mathrm{C}$ namun mengalami penurunan pada suhu $70^{\circ} \mathrm{C}$. Tingkat kemurnian enzim katepsin air cucian surimi paling tinggi terdapat pada suhu $60^{\circ} \mathrm{C}$ yaitu sebesar 89. Hasil tingkat kemurnian tersebut berbeda nyata $(p<0,1)$ pada masing-masing perlakuan.

Tingkat kemurnian air cucian surimi yang diberi perlakuan asam pada $\mathrm{pH} 6$ dan 7 tidak berbeda nyata $(p>0,1)$ namun mengalami kenaikan yang signifikan $(p<0,1)$ seiring dengan penurunan $\mathrm{pH}$. Tingkat kemurnian yang paling tinggi terdapat pada $\mathrm{pH} 3$ yaitu sebesar 108.

Hasil tingkat kemurnian enzim katepsin pada yang diberi perlakuan asam dan suhu mengalami peningkatan yang signifikan $(p<0,1)$ seiring dengan peningkatan $\mathrm{pH}$ sampai pada $\mathrm{pH} 5(0,64 \mathrm{U} / \mathrm{mL})$. Tingkat kemurnian pada $\mathrm{pH} 5$ dan 6 tidak berbeda nyata $(p>0,1)$ namun mengalami penurunan yang signifikan pada $\mathrm{pH} 7(\mathrm{p}<0,1)$. Tingkat kemurnian enzim katepsin yang diberi perlakuan $\mathrm{pH}$ mengalami peningkatan saat dipanaskan pada suhu $60^{\circ} \mathrm{C}$ dari kisaran 67 sampai 108 menjadi 74 sampai 117 . Tingkat kemurnian menjadi optimum pada $\mathrm{pH} 5$ (117). Hal ini sesuai dengan penelitian Seymour et al. (1994) terhadap enzim protease Pacific Whiting yang tingkat kemurniannya meningkat sebanyak 4,1 kali lipat dari ekstrak daging yang disentrifugasi 
pada saat diasamkan pada $\mathrm{pH}$ 5,5 dan dipanaskan pada suhu $60^{\circ} \mathrm{C}$.

\section{KESIMPULAN}

Recovery enzim katepsin dari air cucian surimi terbaik tercapai pada $\mathrm{pH} 5$ dengan pemanasan pada suhu $60^{\circ} \mathrm{C}$ bedasarkan aktivitas spesifik enzim katepsin terhadap kadar protein. Tingkat kemurnian enzim tertinggi mencapai angka 117.

\section{DAFTAR PUSTAKA}

An H, Weerasinghe V, Seymour TA, Morrisey MT. 1994. Chatepsin degradation of Pacific whiting (Merluccius productus) protease. J. Food Sci 59: 277-28I.

An H, Peters MY, Seymour TA, Morrissey MT. 1995. Isolation and activation of cathepsin $L$ inhibitor complex from Pacific whiting (Merluccius productus). J. Agric. Food Chem. 43: 327-330.

[AOAC] Association of Official Analytical Chemist. 2005. Official Method of Analysis of The Association of Official Analytical of Chemist. Arlington (US): The Association of Official Analytical Chemist, Inc.

Balti F, Noomen H, Kemel J, Naima NA, Guillochon D, Moncef N. 2010. Cathepsin D from hepatopancreas of the cuttlefish (Sepia officinalis): purification and characterization. J. Agric. Food Chem. 19:10623-10630.

Bender DA. 2002. Introduction to Nutrition and Metabolism. Vol. I. New York (US): Taylor \& Francis Inc.

Benjakul S, Seymour, TA, Morrissey MT, An H. 1996. Proteinase in Pacific whiting surimi wash water: identification and characterization. J. Food Sci. 61: I I65-I I70.

Bisswanger H. 2008. Enzyme Kinetics: Principles and Methods $2^{\text {nd }}$ Edition. Weinheim (DE): Wiley$\mathrm{VCH}$.

Bourtoom T. Chinnan MS, Jantawat $P$, Sanguandeekul R. 2009. Recovery and characterization of proteins precipitated from surimi wash-water. J. Food Sience and Technol. 42:599-605.
Bradford MM. 1976. A rapid and sensitive method for quantification of microgram quantities of protrein utilizing the principle of protein dye binding. Anal Biochem 72: 234-254.

Campbell MK, Farrel SO. 2006. Biochemistry 5th Edition. Belmont (US): Thompson Brooks/Cole.

Choi, Kang, Lanier. 2005. Surimi and Surimi Seafood. Boca Raton (US): CRC Press.

DeWitt CAM, Morrisey MT. 200I. Parameters for recovery of proteases from surimi wash water. Bioresour. Technol. 8I: 24I-247.

Dinu D, Dumitru IF, Neichifor MT. 2002. Isolation and characterization of two chatepsin from muscle of Carrasius auratus gibelio. Roum. Biotecnol. Lett 7(3): 753-758.

Doonan S, Cutler P. 2004. Protein Purification Protocols $2^{\text {nd }}$ Edition. New Jersey (US): Humana Press Inc.

El-Yassin HD. 2012. Enzymes Assay.[internet]. [diunduh 18 September 2013]. Tersedia pada http://www.comed.uobaghdad.edu.iq

Haard NF. 1992. A review of proteolytic enzymes from marine organism and their application in the food industry. J. Aquat. Food Prod. Technol I: 17-35

Jiang ST, Her YH, Lee JJ, and Jeng HW. 2002. Comparison of the cathepsin $\mathrm{D}$ from mackerel (Scomber australasicus) and milkfish (Chanos chanos) muscle. Bioscience, Biotech, Biochem. 57(4): 57I-577.

Krause J, Shonisani C, Tshidino, Tomohisa O, Yasuharu, Vaughan, Benesh S, Muramoto K, Ryno JN. 20I0. Purification and partial characterization of ostrich skeletal muscle cathepsin $D$ and its activity during meat maturation. Journal Meat Science. 87(3):196-20I.

Lehninger AL. 1993. Dasar-Dasar Biokimia. jilid I. M. Thenawidjaja, penerjemah. Jakarta: Erlangga. Terjemahan dari: Principle of Biochemistry.

Lin TM, Park JW, Morrissey MT. 1995. Recovered proteins and reconditioned water from surimi processing waste. J. Food. Sci. 50(I): 4-9.

Seymour TA, Morrissey MT, Peters MY, An H. 1994. Purification and characterization of Pasific whiting proteases. J. Agric. Food Chem. 42:2421-2427.

Toyohara H, Makinodan Y, lkeda S. 198I. Purification and properties of carp muscle 
cathepsin A. Bull. Japan. Soci. Sci. Fish. 48(8):

$1145-1150$.

\section{LAMPIRAN}

Tabel I Pembuatan larutan standar BSA konsentrasi 0,04-3,2 mg/mL

\begin{tabular}{ccc}
\hline $\begin{array}{c}\text { Konsentrasi BSA } \\
(\mathrm{mg} / \mathrm{mL})\end{array}$ & Volume BSA $(\mathrm{mL})$ & Volume akhir $(\mathrm{mL})$ \\
\hline 0 & 0 & $10 \mathrm{~mL}$ \\
0,4 & 1,25 & $10 \mathrm{~mL}$ \\
0,8 & 2,50 & $10 \mathrm{~mL}$ \\
1,2 & 3,75 & $10 \mathrm{~mL}$ \\
1,6 & 5,00 & $10 \mathrm{~mL}$ \\
2,0 & 6,25 & $10 \mathrm{~mL}$ \\
2,4 & 7,50 & $10 \mathrm{~mL}$ \\
2,8 & 8,75 & $10 \mathrm{~mL}$ \\
3,2 & 10,00 & $10 \mathrm{~mL}$ \\
\hline
\end{tabular}

Tabel 2 Hasil analisis kimia air cucian surimi

\begin{tabular}{lll}
\hline No & Parameter & Hasil \\
\hline 1 & Air (basis basah) & $98,21 \%$ \\
2 & Abu & $0,19 \%$ \\
3 & Protein & $0,88 \%$ \\
4 & Aktivitas Enzim Katepsin & $0,14 \mathrm{U} / \mathrm{mL}$ \\
5 & Aktivitas Spesifik Enzim Katepsin & $0,15 \mathrm{U} / \mathrm{mg}$ \\
\hline
\end{tabular}

Tabel 3 Aktivitas spesifik dan tingkat kemurnian enzim katepsin pada masing-masing perlakuan

\begin{tabular}{ccc}
\hline Perlakuan & $\begin{array}{c}\text { Aktivitas Spesifik } \\
(\mathrm{U} / \mathrm{mg})\end{array}$ & $\begin{array}{c}\text { Tingkat } \\
\text { Kemurnian }\end{array}$ \\
\hline Air Cucian Surimi & 0,15 & $\mathrm{I}$ \\
Pemanasan Suhu $30^{\circ} \mathrm{C}$ & 6,74 & 44 \\
Pemanasan Suhu $40^{\circ} \mathrm{C}$ & 8,87 & 58 \\
Pemanasan Suhu $50^{\circ} \mathrm{C}$ & 10,03 & 65 \\
Pemanasan Suhu $60^{\circ} \mathrm{C}$ & 13,63 & 89 \\
Pemanasan Suhu $70^{\circ} \mathrm{C}$ & 11,17 & 73 \\
Pengasaman $\mathrm{pH} \mathrm{3}$ & 16,64 & 108 \\
Pengasaman $\mathrm{pH} 4$ & 15,57 & 102 \\
Pengasaman $\mathrm{pH} 5$ & 12,08 & 79 \\
Pengasaman $\mathrm{pH} 6$ & 10,95 & 71 \\
Pengasaman $\mathrm{pH} 7$ & 10,26 & 67 \\
Pengasaman $\mathrm{pH} 3$ dengan pemanasan suhu $60^{\circ} \mathrm{C}$ & 14,72 & 96 \\
Pengasaman $\mathrm{pH} 4$ dengan pemanasan suhu $60^{\circ} \mathrm{C}$ & 16,22 & 106 \\
Pengasaman $\mathrm{pH} 5$ dengan pemanasan suhu $60^{\circ} \mathrm{C}$ & 17,90 & 117 \\
Pengasaman $\mathrm{pH} 6$ dengan pemanasan suhu $60^{\circ} \mathrm{C}$ & 17,48 & 114 \\
Pengasaman $\mathrm{pH} 7$ dengan pemanasan suhu $60^{\circ} \mathrm{C}$ & 11,40 & 74 \\
\hline
\end{tabular}




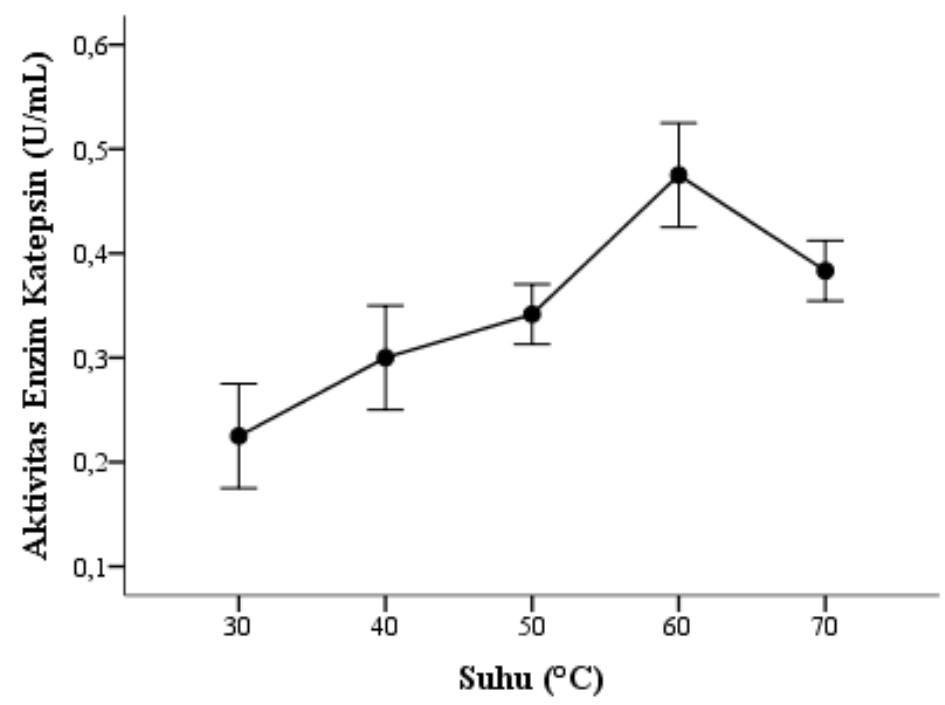

Gambar I Pengaruh suhu terhadap aktivitas enzim katepsin pada air cucian surimi

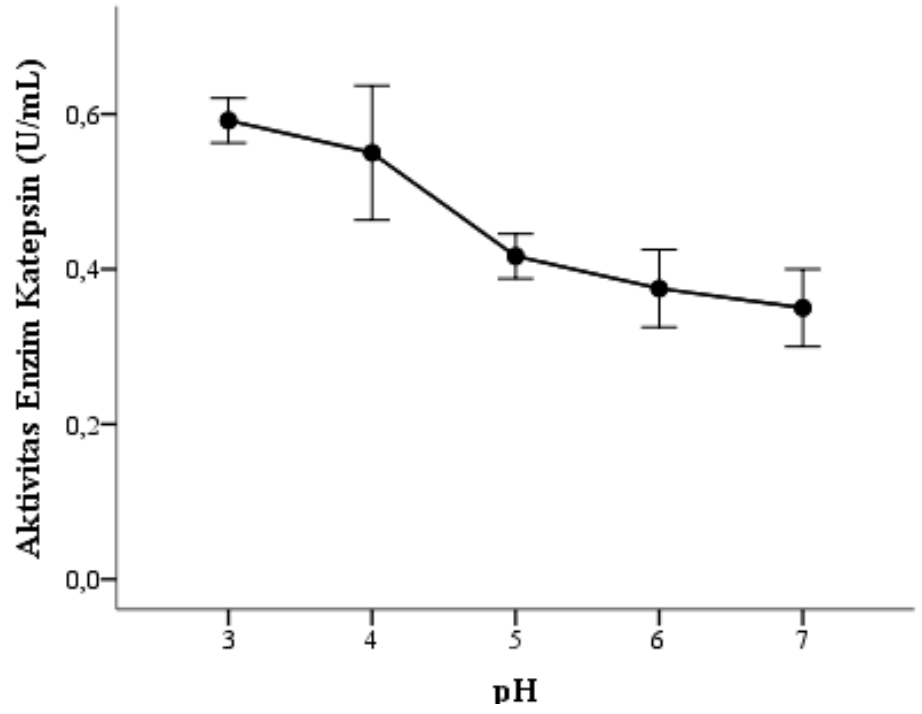

Gambar 2 Pengaruh pH terhadap aktivitas enzim katepsin

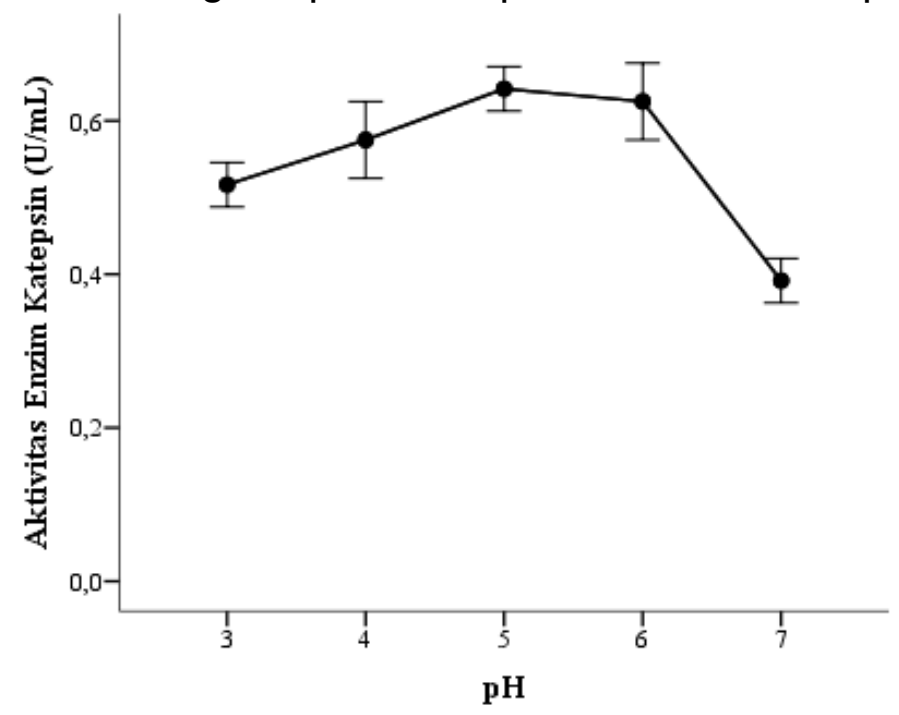

Gambar 3 Pengaruh pH dan pemanasan pada suhu $60^{\circ} \mathrm{C}$ terhadap aktivitas enzim katepsin 


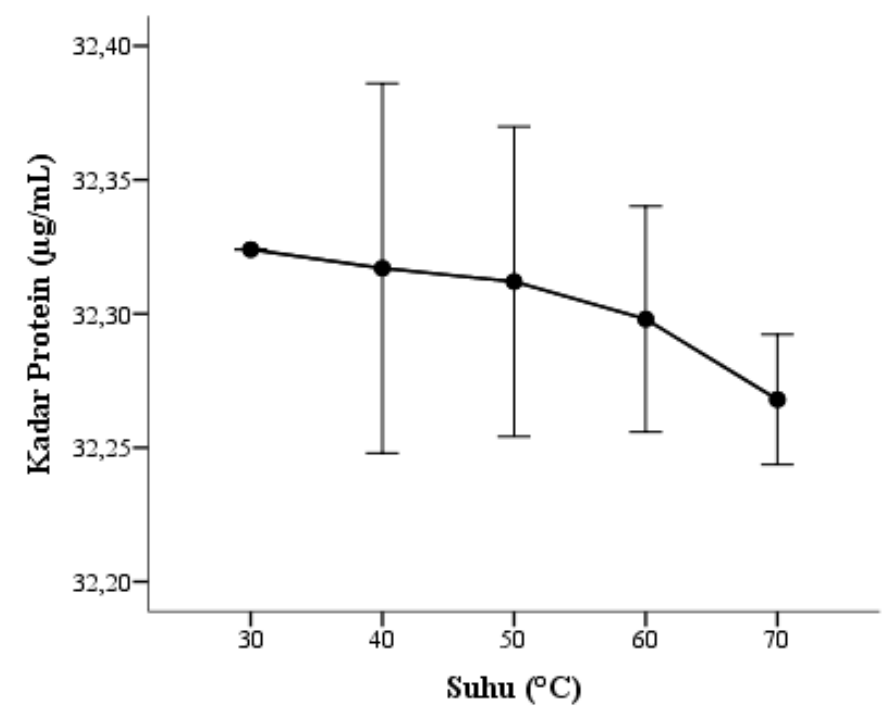

Gambar 4 Pengaruh suhu terhadap kadar protein air cucian surimi

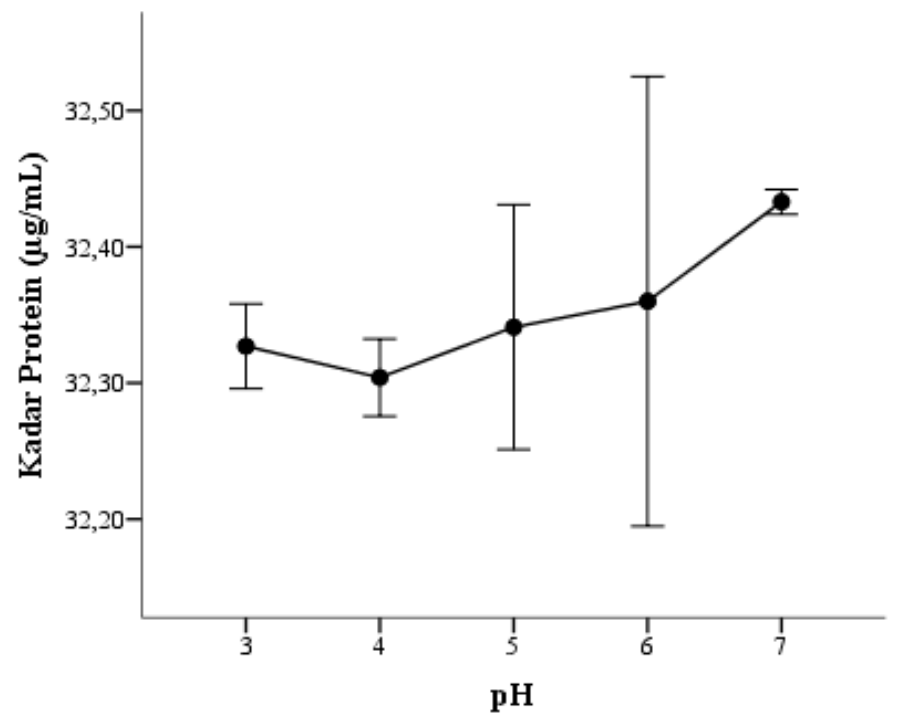

Gambar 5 Pengaruh pH terhadap kadar protein air cucian surimi

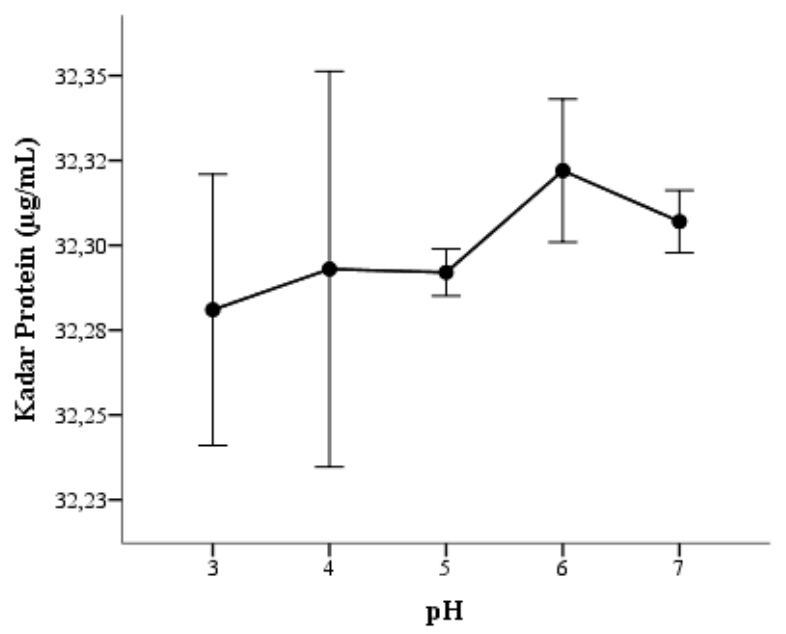

Gambar 6 Pengaruh pH dan pemanasan pada suhu $60^{\circ} \mathrm{C}$ terhadap kadar protein air cucian surimi 


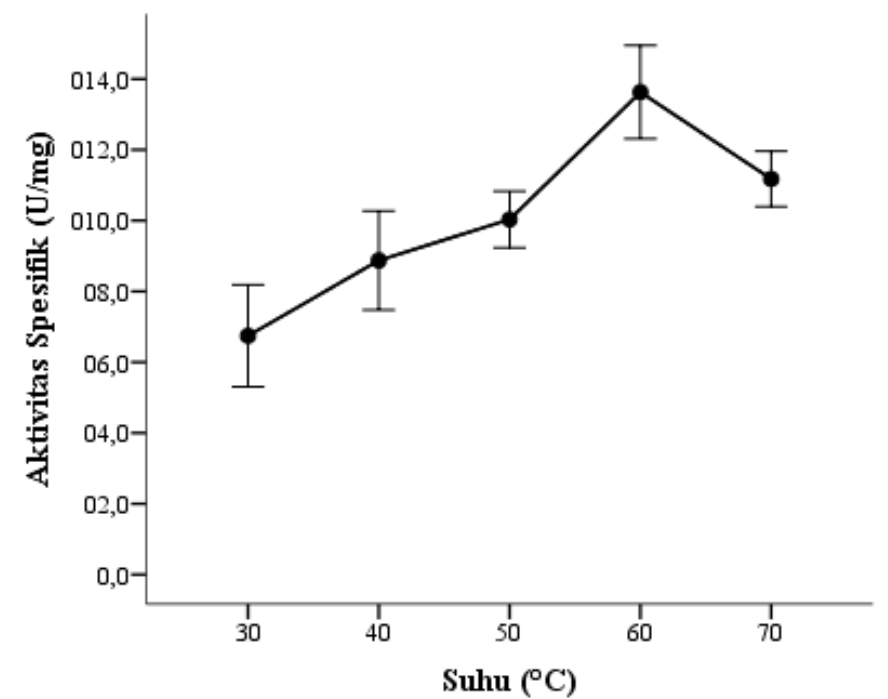

Gambar 7 Pengaruh suhu terhadap aktivitas spesifik enzim katepsin

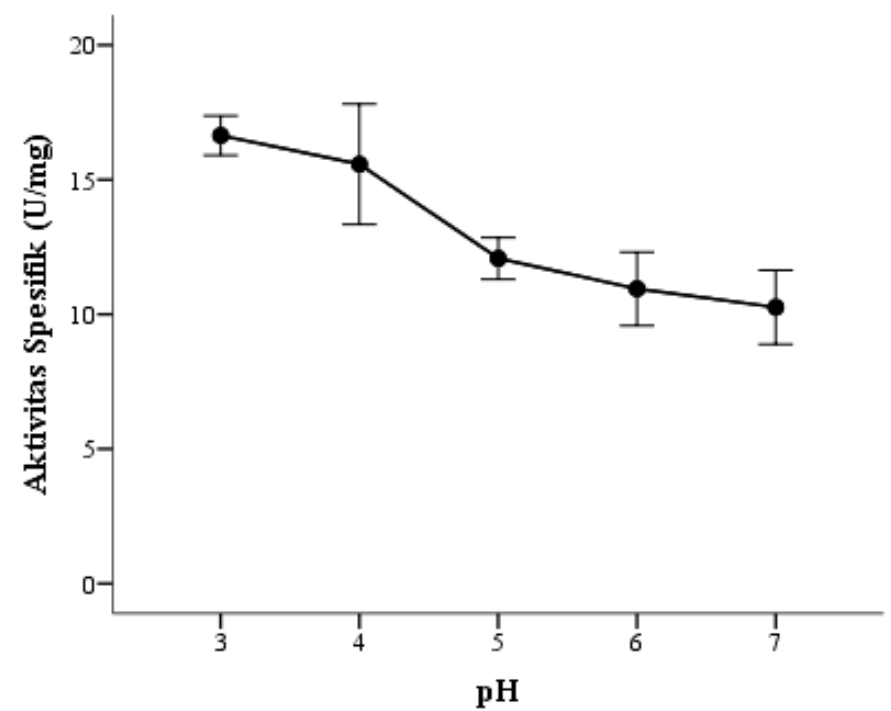

Gambar 8 Pengaruh pH terhadap aktivitas spesifik enzim katepsin

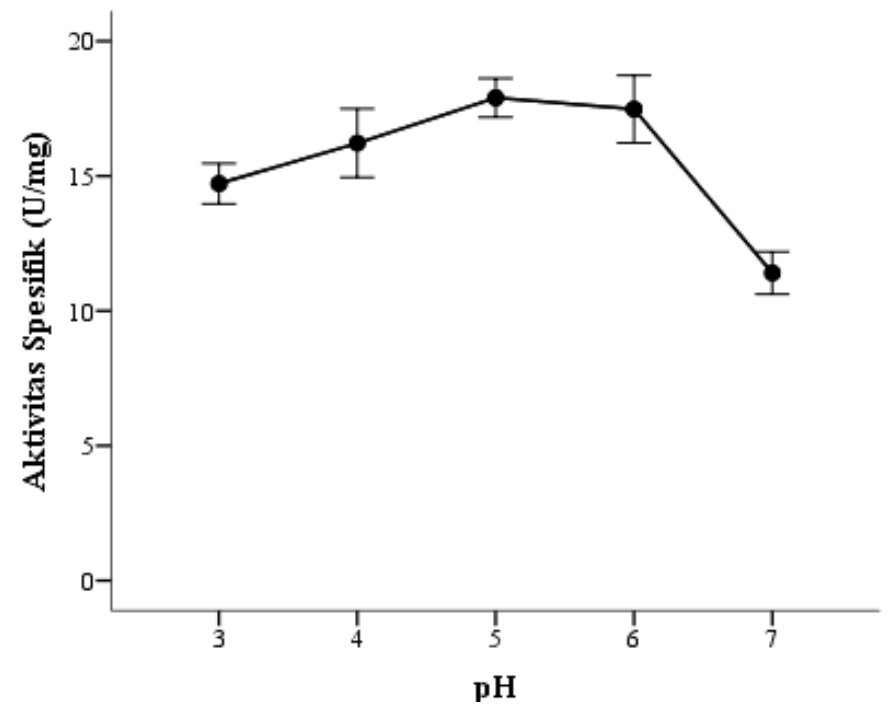

